\title{
A pilot study on the endoscopic surveillance of colorectal dysplasia and cancer in long-standing ulcerative colitis
}

\author{
S. Khorrami Mashhadi, M. Trapero, J. P. Gisbert, E. Gómez Domínguez and J. Maté-Jiménez \\ Service of Digestive Diseases. Hospital Universitario de La Princesa. Madrid, Spain
}

\begin{abstract}
Introduction: patients with ulcerative colitis (UC) have a greater risk of developing colorectal cancer $(\mathrm{CRC})$ when compared to the general population. Epithelial dysplasia comes before this neoplasm, and thus endoscopic surveillance is recommended to these patients. This pilot study aims at establishing the incidence of dysplasia and $\mathrm{CRC}$ in patients with long-standing UC in our hospital.

Material and methods: this is a prospective observational study performed in patients with a definite diagnosis of UC for more than 8 years. These patients were encouraged to enroll in an endoscopic surveillance program for CRC. All patients underwent colonoscopy and multiple biopsies every 18 to 24 months in order to detect epithelial dysplasia.

Results: thirty-nine patients were included from January 1994 to December 2003. Half of them were males. Mean age was $52 \pm 13$ years. Mean duration of UC was $15 \pm 8$ years. Thirteen (35\%) patients had left colitis, and $26(65 \%)$ had pancolitis or extensive colitis. The presence of mild dysplasia was detected in four patients, on two occasions in one of them $(13 \%$; $95 \% \mathrm{CI}$ : 6.1-33.5); the incidence of mild dysplasia was $1.3 \%$ patients per surveillance year. No severe dysplasia or CRCs were identified.

Conclusion: the incidence of dysplasia in our area is lower than expected, and does not support surveillance programs for these patients. However, no definite conclusions may be drawn from such a small number of patients.
\end{abstract}

Key words: Dysplasia. Ulcerative colitis. Colorectal carcinoma. Inflammatory bowel disease.

Khorrami Mashhadi S, Trapero M, Gisbert JP, Gómez Domínguez E, Maté-Jiménez J. A pilot study on the endoscopic surveillance of colorectal dysplasia and cancer in long-standing ulcerative colitis. Rev Esp Enferm Dig 2005; 97: 16-23.

Recibido: 25-03-04.

Aceptado: 18-05-04.

Correspondencia: José Maté Jiménez. Po Alameda de Osuna, 159. 28042 Madrid. Telf.: 915202254 - Fax: 914022 299. e-mail: jmatej@mixmail.com; mtraperomarugan@terra.es

\section{INTRODUCTION}

Patients with ulcerative colitis (UC) have a greater risk of developing colorectal cancer (CRC) when compared with the general population, particularly those who suffer from extensive or long-standing disease (1). In a recent meta-analysis, the overall incidence of CRC in UC was estimated as 3 per 1000 patients/year (2). In extensive colitis and pancolitis, the cummulative risk of this complication is $2-5 \%$ per year during the first 10 years of disease, $5-10 \%$ per year during the second decade, and $12-20 \%$ per year over the third decade (25). Left colitis entails a similar increased risk of CRC a decade later than more extensive disease $(6,7)$. It is currently admitted that dysplasia is a disease stage that heralds CRC, and its presence in colic mucosal biopsies predicts a concurrent carcinoma or a high-risk situation, particularly in case of a high-grade dysplasia or a dysplasia-associated lesion or mass (DALM) $(5,8)$. In order to reduce CRC-related mortality in these patients, regular colonoscopies with multiple biopsy samples are recommended to detect dysplasia (9-11). The incidence of post-colitis CRC and dysplasia is unknown in our setting, and thus the cost-effectiveness of this strategy remains unproven.

This work attempts to be a pilot study to approach actuality and to allow the planning of a prospective research to establish the incidence of dysplasia and CRC in patients with long-standing UC in Spain.

\section{MATERIAL AND METHODS}

This is a pilot, prospective, observational study performed in patients definitely diagnosed with long-standing UC who were encouraged to enroll in an endoscopic surveillance program for CRC. 


\section{Source and characteristics of patients}

Patients included in the endoscopic surveillance program for post-colitis CRC came from a monographic inflammatory bowel disease clinic in our hospital, and provided their signed informed consent. Demographic data for patients are partially listed on table I. A total of 39 patients were consecutively included in the surveillance program from January 1994 to December 2003. The male:female ratio was 1 , and mean age was $52 \pm 13$ years. Mean UC duration was $17.8 \pm 8$ years. Mean time within the program was $4.6 \pm 5$ years, and $2.5 \pm 2$ colonoscopies per patient were performed on average. Thirteen (35\%) patients had left colitis, and $26(65 \%)$ had pancolitis or extensive colitis.

\section{Definitions}

The diagnosis of UC was established based on suggestive endoscopic findings (erythematous, edematous, ulcerated mucosa with either spontaneous or contact-related vascular friability), consistent histological findings, and follow-up for more than 8 years.

The extension of UC was determined based on an endoscopic examination of the colon during a flare-up of disease.

1. Pancolitis: the lesion extends beyond the hepatic angle of the colon.

2. Extensive colitis: the lesion extends beyond the splenic angle of the colon but does not reach the hepatic flexure.

3. Left colitis: the lesion extends beyond the rectum without ever reaching the splenic flexure.

Long-standing UC: it was considered that of more than 8 years' standing for pancolitis and extensive colitis, and more than 10 years' standing for left colitis.

Dysplasia: this was defined as a neoplastic proliferation of epithelial cells at the colic mucosa during inflammatory remission and with no evidence of submucosal invasion. The diagnosis was confirmed by at least two staff pathologists.

Dysplasia grades: low-grade or mild dysplasia was defined as a dysplasia where most foci of neoplastic cells lay deep within glands, whereas high-grade or severe dysplasia was defined as a dysplasia sporting greater cell disruption.

Maintenance therapy using 5-ASA: patients on this medication were taking at least $1.2 \mathrm{~g}$ of 5-ASA indefinitely since diagnosis, with interruptions only during steroidal therapy periods.

\section{Methods}

All patients with a diagnosis of UC for more than 8 years and with an extension greater than $15 \mathrm{~cm}$ were en- couraged to undergo surveillance regarding their involved colic mucosa. In order to rule out the presence of UC-associated colic dysplasia and/or colon carcinoma, patients who agreed to enroll in the study underwent colonoscopy during clinical remission periods and every 18-24 months, with multiple biopsy sampling. The total number of biopsies ranged between 25 and more than 30 for patients with extensive colitis or pancolitis, and from 10 to 15 for patients with left colitis. No samples from unaffected mucosal areas were collected. Samples were examined by two pathologists to establish the presence of dysplasia, grade of dysplasia, and presence of carcinoma. Figure 1 describes the management of patients according to endoscopic and histological findings. In the absence of dysplasia, patients underwent regular endoscopic surveillance with biopsy collection every 18-24 months. Should dysplasia be identified in a mucosal setting lacking endoscopic or histological evidence of inflammation, a new examination with biopsy sampling would be indicated following complete inflammatory remission. In the presence of mild dysplasia with no evidence of mucosal inflammation, a new endoscopy with biopsy sampling would be indicated after 3 months. For severe dysplasia without inflammation, a new exploration with biopsy collection would be indicated after 4 weeks. Finally, for severe dysplasia and no inflammation identified during two consecutive procedures, patients would be referred to a surgeon for prophylactic pancolectomy. The primary endpoint of the endoscopic surveillance program was dysplasia development. Other endpoints assessed included duration of disease, presence or absence of endoscopic activity when dysplasia was detected, and dysplasia regression following maintenance therapy with 5-ASA.

\section{Statistical analysis}

A descriptive statistical analysis was performed by estimating mean and standard deviation values for quantitative variables, and percentages and $95 \%$ confidence intervals (95\% CIs) for qualitative variables. An SPSS 11.0 software pack was used.

\section{RESULTS}

The presence of mild dysplasia was identified in 4 patients, on two occasions separated by 5 years in one of them (13\%; 95\% CI: 6.1-33.5); the incidence of mild dysplasia was $1.3 \%$ patients per surveillance year. No severe dysplasias or CRCs were detected. Table I summarizes the characteristics of patients with and without mild dysplasia in colic mucosa biopsies. Of five mild dysplasias identified, four (80\%) had developed on a mucosa with endoscopic evidence of acute inflammation despite the fact that patients lacked symptoms suggesting an acute flare-up. Table II shows the performance of a fol- 


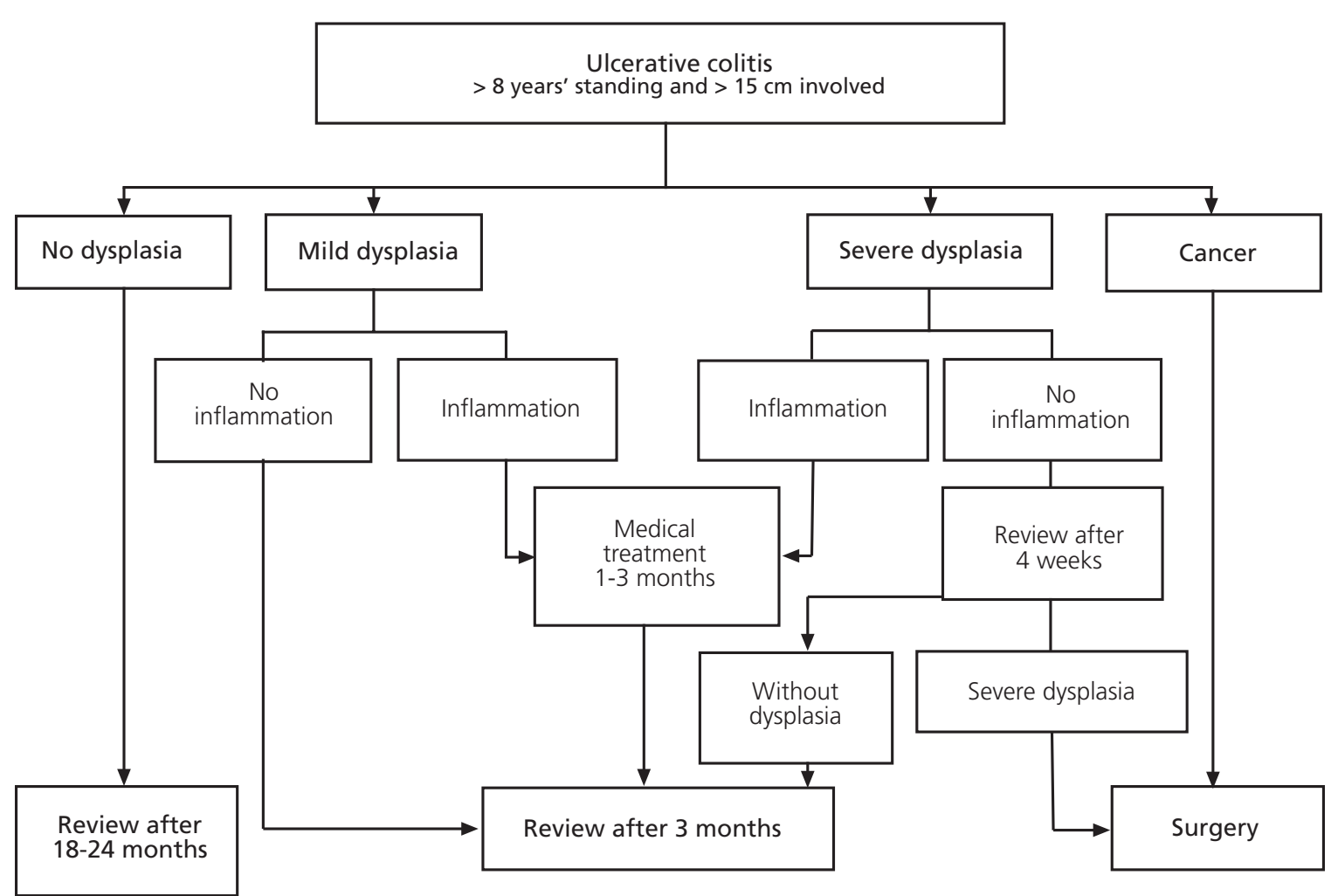

Fig. 1.- Management of dysplasia and/or carcinoma in our endoscopic surveillance program for patients with long-standing ulcerative colitis. Manejo de la displasia y/o carcinoma en nuestro programa de vigilancia endoscópica en pacientes con colitis ulcerosa de larga evolución.

Table I. Characteristics of patients with mild dysplasia and no dysplasia

\begin{tabular}{lcc}
\hline & Mild dysplasia & No dysplasia \\
\hline Number & 4 & 35 \\
Gender (males: females) & $4: 0$ & $16: 19$ \\
Age (years)* & $58 \pm 6$ & $51 \pm 14$ \\
Extension of ulcerative colitis & & \\
$\quad$ Pancolitis/ Extensive & $4(50 \%)$ & $26(65 \%)$ \\
$\quad$ Left & 0 & $13(35 \%)$ \\
Evolution time (years)* & $23.2 \pm 6$ & $16.9 \pm 9$ \\
Time within program (years)* & $6.2 \pm 4$ & $4.4 \pm 3$ \\
Number of colonoscopies with biopsies* & $5.2 \pm 3$ & $1.9 \pm 1$ \\
5-ASA for maintenance** & $4(100 \%)$ & $25(64 \%)$ \\
\hline
\end{tabular}

*Mean \pm standard deviation; **these patients were never on immunomodulators for maintenance therapy.

low-up protocol for patients with long-standing UC. Table III shows the characteristics of the four patients in whom dysplastic lesions were seen. No significance levels are expressed since the small number of dysplasias encountered renders statistical results unreliable.
Table II. Time within the endoscopic surveillance program and number of dysplastic lesions

\begin{tabular}{lcc}
\hline $\begin{array}{l}\text { Time within program } \\
\text { (years) }\end{array}$ & $\begin{array}{c}\text { No. of } \\
\text { patients }\end{array}$ & $\begin{array}{c}\text { Dysplastic } \\
\text { lesions }\end{array}$ \\
\hline$<3$ years & $25(64 \%)$ & $1^{*}$ \\
$3-5$ years & $8(20 \%)$ & 0 \\
$>5$ years & $6(15 \%)$ & $4^{* *}$ \\
\hline
\end{tabular}

*1 year since inclusion in surveillance program, but 20 years with extensive UC. $* * 2$ mild dysplasias in one patient.

\section{DISCUSSION}

No carcinoma or high-grade dysplasia was detected in our patients. Of note, all mild dysplasias except one were seen on inflamed mucosa, despite the fact that patients had no symptoms suggesting acute disease, which raises suspicion that lesions were reactive to the inflammation. Similarly, all lesions regressed in one to three months after high-dose 5-ASA administration. No association or progression from mild dysplasia to high-grade dysplasia or carcinoma was seen. These results are in accordance with the clinical impression that UC-associated CRC is uncommon in our patients, and consequently deviate from cumulative experience by other teams (1-8). 
Table III. Characteristics of patients with UC and mild dysplasia

\begin{tabular}{|c|c|c|c|c|c|c|c|c|c|}
\hline Patients & Gender & Age & $\begin{array}{c}\text { UC } \\
\text { extension }\end{array}$ & $\begin{array}{l}\text { Evolution } \\
\text { time (years) }\end{array}$ & $\begin{array}{l}\text { Surveillance } \\
\text { time (years) }\end{array}$ & $\begin{array}{c}\text { Number of } \\
\text { endoscopies }\end{array}$ & $\begin{array}{c}\text { Endoscopic } \\
\text { activity }\end{array}$ & $\begin{array}{l}\text { Repeat } \\
\text { biopsies }\end{array}$ & 5-ASA \\
\hline 1 & Male & 51 & Pancolitis & 19 & 7 & 4 & Yes & No dysplasia & Yes \\
\hline 2 & Male & 58 & Extensive colitis & 20 & 1 & 2 & Yes & No dysplasia & Yes \\
\hline 3 & Male & 60 & Pancolitis & 21 & 7 & 7 & Yes & No dysplasia & Yes \\
\hline 4 & Male & 65 & Extensive colitis & 33 & 10 & 9 & No & No dysplasia & Yes \\
\hline
\end{tabular}

The reason for these surprising results may be difficult to explain, and may involve a bias resulting from the small number of patients included in the program, further complicated by a short follow-up period. Similarly, other factors such as the high percentage of patients on 5-ASA, which seems to exert a protective effect against CRC development (9-17), or the varying incidence of CRC in our area's general population, which is less than half of that observed in other Western countries, may play a role (18).

While we have no better diagnostic method available for clinical practice, the incidence of dysplasia among patients with ulcerative colitis may likely not be representative of the incidence of UC-associated carcinoma. The true predictive value of mild dysplasia in CRC identification is still controversial. Its usefulness seemed scarce in early studies, as only $16-29 \%$ of patients progressed to more aggressive lesions $(5,8,12)$. Unified histological criteria have improved this marker's specificity for the detection of malignant lesions. Connell et al. reported an increased predictive value, from $16 \%$ at baseline to $54 \%$, upon reviewing 128 biopsies consistent with low-grade dysplasia (12). After 32 months of follow-up, on reassessing the biopsies from 18 patients with long-standing UC and mild dysplasia, Ullman et al. reported lesion progression in $50 \%$ of cases, with a cumulative incidence of $33 \%$ at 5 years for high-grade dysplasia or carcinoma (14). In a more recent paper, this same author reported that low-grade dysplasia progressed in $30 \%$ of patients, with a progression rate of $53 \%$ at 5 years (19). In contrast, another paper identified mild dysplasia progression in only $10 \%$ of patients on reviewing biopsies from a cohort including 128 patients undergoing surveillance for 10 years $(20)$.

Interobserver and intraobserver variability is high in the histological diagnosis of mild dysplasia, with only $50-60 \%$ of agreement between every two expert pathologists $(21,22)$. Added to the inability to obtain biopsies from the whole colon, this would raise the number of false positive results and -what is more- false negative results. We believe that the number of biopsies collected and the extent of colon examined in our surveillance program suffice. Since dysplasia is a patchy lesion (20), the American Gastroenterological Association (AGA), American Society of Gastrointestinal Endoscopy (ASGE), and British Society of Gastroenterolo- gy $(12,23)$ recommend that the colon be fully explored regardless of disease extension, and that 2-4 biopsy samples every $10 \mathrm{~cm}$ be collected. This translates in greater costs and greater patient discomfort. In addition, a great majority of tumors and premalignant lesions are found in the furthermost reaches of the colon, and up to $25 \%$ of post-colitis carcinomas are not associated with dysplasia (19,24-27). Hence, such recommendations were categorized as "grade C", that is, as having only moderate evidence supporting their efficacy, with benefits closely matching adverse effects, which advises against their widesprad application (28).

In view of all previous information, and given ours was a small pilot study, our results should be considered an approach to actuality. In order to establish the costbenefit ratio of a screening program for post-colitis carcinoma, further extensive, prospective, and multicenter studies are called for to determine the true incidence of CRC in long-standing UC in our setting.

\section{ACKNOWLEDGEMENT}

Supported in part by a grant from the Instituto de Salud Carlos III (C03/02).

\section{REFERENCES}

1. Langholz E, Munkholm P, Davidsen M, Binder V. Colorectal cancer risk and mortality in patients with ulcerative colitis. Gastroenterology 1992; 103: 1444-51.

2. Eaden JA, Abrams KR, Mayberry JF. The risk of colorectal cancer in ulcerative colitis: a meta-analysis. Gut 2001; 48: 526-35.

3. Ekbom A, Helmick C, Zack M, Adami HO. Ulcerative colitis and colorectal cancer. A population-based study. N Engl J Med 1990; 323: 1228-33.

4. Gyde SN, Prior P, Allan RN, Stevens A, Jewell DP, Truelove SC, et al. Colorectal cancer in ulcerative colitis: a cohort study of primary referrals from three centres. Gut 1988; 29: 206-17.

5. Lennard-Jones JE, Melville DM, Morson BC, Ritchie JK, Williams $\mathrm{CB}$. Precancer and cancer in extensive ulcerative colitis: findings among 401 patients over 22 years. Gut 1990; 31: 800-6.

6. Connell WR, Lennard-Jones JE, Williams CB, Talbot IC, Price AB, Wilkinson KH. Factors affecting the outcome of endoscopic surveillance for cancer in ulcerative colitis. Gastroenterology 1994; 107 : 934-44.

7. Lindberg B, Persson B, Veress B, Ingelman-Sundberg H, Granqvist $\mathrm{S}$. Twenty years' colonoscopic surveillance of patients with ulcerative colitis. Detection of dysplastic and malignant transformation. Scand J Gastroenterol 1996; 31: 1195-204. 
8. Ullman TA, Loftus EV Jr., Kakar S, Burgart LJ, Sandborn WJ, Tremaine WJ. The fate of low grade dysplasia in ulcerative colitis. Am J Gastroenterol 2002; 97: 922-7.

9. Levin B. Risk of cancer in ulcerative colitis. Gastrointest Endosc 1999; 49: S60-2.

10. Nugent FW, Haggitt RC, Gilpin PA. Cancer surveillance in ulcerative colitis. Gastroenterology 1991; 100: 1241-8.

11. Bernstein CN, Shanahan F, Weinstein WM. Are we telling patients the truth about surveillance colonoscopy in ulcerative colitis? Lancet 1994; 343: 71-4.

12. Kornbluth A, Sachar DB. Ulcerative colitis practice guidelines in adults. American College of Gastroenterology, Practice Parameters Committee. Am J Gastroenterol 1997; 92: 204-11.

13. Eaden JA, Mayberry JF. Guidelines for screening and surveillance of asymptomatic colorectal cancer in patients with inflammatory bowel disease. Gut 2002; 51 (Supl. 5): V10-2.

14. Provenzale D, Onken J. Surveillance issues in inflammatory bowel disease: ulcerative colitis. J Clin Gastroenterol 2001; 32: 99-105.

15. Pinczowski D, Ekbom A, Baron J, Yuen J, Adami HO. Risk factors for colorectal cancer in patients with ulcerative colitis: a case-control study. Gastroenterology 1994; 107: 117-20.

16. Eaden J, Abrams K, Ekbom A, Jackson E, Mayberry J. Colorectal cancer prevention in ulcerative colitis: a case-control study. Aliment Pharmacol Ther 2000; 14: 145-53.

17. Ryan BM, Russel MG, Langholz E, Stockbrugger RW. Aminosalicylates and colorectal cancer in IBD: a not-so bitter pill to swallow. Am J Gastroenterol 2003; 98: 1682-7.

18. Registro de Cáncer de Navarra. Sección de enfermedades no transmisibles y estadísticas vitales. Incidence and mortality of cancer in Navarra, 1993-1997. Tendencies in the last 25 years. An Sist Sanit Navar 2001; 24: 339-62.
19. Ullman TA, Croog V, Harpaz N, Sachar DB, Itzkowitz S. Progresion of flat low-grade dysplasia to advanced neoplasia in patients with ulcerative colitis. Gastroenterology 2003; 125: 1311-9.

20. Rubin CE, Haggitt RC, Burmer GC, Brentnall TA, Stevens AC, Levine DS, et al. DNA aneuploidy in colonic biopsies predicts future development of dysplasia in ulcerative colitis. Gastroenterology 1992; 103: 1611-20.

21. Eaden J, Abrams K, McKay H, Denley H, Mayberry J. Inter-observer variation between general and specialist gastrointestinal pathologists when grading dysplasia in ulcerative colitis. J Pathol 2001; 194: 152-7.

22. Lim CH, Dixon MF, Vail A, Forman D, Lynch DA, Axon AT. Ten year follow up of ulcerative colitis patients with and without low grade dysplasia. Gut 2003; 52: 1127.

23. The role of colonoscopy in the management of patients with inflammatory bowel disease. Gastrointest Endosc 1998; 48: 689-90.

24. Prior P, Gyde SN, Macartney JC, Thompson H, Waterhouse JA, Allan RN. Cancer morbidity in ulcerative colitis. Gut 1982; 23: 490-7.

25. Slater G, Greenstein AJ, Gelernt I, Kreel I, Bauer J, Aufses AH Jr. Distribution of colorectal cancer in patients with and without ulcerative colitis. Am J Surg 1985; 149: 780-802.

26. Choi PM. Predominance of rectosigmoid neoplasia in ulcerative colitis and its implication on cancer surveillance. Gastroenterology 1993; 104: 666-7.

27. Connell WR, Talbot IC, Harpaz N, Britto N, Wilkinson KH, Kamm MA, et al. Clinicopathological characteristics of colorectal carcinoma complicating ulcerative colitis. Gut 1994; 35: 1419-23.

28. Harris R, Helfand M, Woolf S, Lohr K, Mulrow C, Teutsch S, et al. for the Methods Work Group, Third U.S. Preventive Services Task Force. Current methods of the U.S. Preventive Services Task Force: a review of the process. Am J Prev Med 2001; 20: 21-35.

\title{
Estudio piloto sobre la vigilancia endoscópica de la displasia y del cáncer colorrectal en la colitis ulcerosa de larga evolución
}

\author{
S. Khorrami Mashhadi, M. Trapero, J. P. Gisbert, E. Gómez Domínguez y J. Maté-Jiménez \\ Servicio de Aparato Digestivo. Hospital Universitario de La Princesa. Madrid
}

\section{RESUMEN}

Introducción: los pacientes con colitis ulcerosa (CU) tienen un mayor riesgo de desarrollar cáncer colorrectal (CCR) que la población general. La displasia epitelial precede a esta neoplasia por lo que se recomienda la vigilancia endoscópica de estos pacientes Este estudio piloto pretende determinar la incidencia de la displasia y del CCR en pacientes con CU de larga evolución en nuestro hospital.

Material y métodos: estudio prospectivo y observacional en pacientes con el diagnóstico firme de CU de más de 8 años de evolución a los que se propuso entrar en un programa de vigilancia endoscópica del CCR. A todos los enfermos se les sometió cada 18/24 meses a una colonoscopia con múltiples biopsias para detectar displasias epiteliales.

Resultados: se incluyeron 39 pacientes desde enero de 1994 hasta diciembre de 2003. La mitad de ellos eran varones. La edad media fue de 52 años ( \pm 13 años). La duración media de la CU fue de $15 \pm 8$ años. Trece (35\%) enfermos sufrían una colitis izquierda y 26 (65\%) una pancolitis o colitis extensa. Se detectó la presencia de displasia leve en 4 pacientes, en uno de ellos en dos ocasiones (13\%, IC 95\%: 6,1-33,5), la incidencia de displasia leve fue de $1,3 \%$ pacientes por año de vigilancia. No se detectaron displasias graves ni CCRs.

Conclusión: la incidencia de displasia en nuestra área es menor que la esperada y no sustenta los programas de vigilancia en estos enfermos. Aunque por el pequeño número de pacientes no se pueden sacar conclusiones firmes.

Palabras clave: Displasia. Colitis ulcerosa. Carcinoma colorrectal. Enfermedad inflamatoria intestinal. 


\section{INTRODUCCIÓN}

Los pacientes con colitis ulcerosa (CU) tienen un mayor riesgo de desarrollar cáncer colorrectal (CCR) que la población general, especialmente aquellos con una forma extensa y de larga evolución de la enfermedad (1). En un reciente metanálisis, la incidencia global del CCR en la CU se estima en 3 por 1.000 pacientes/año (2). En la colitis extensa y la pancolitis, el riesgo acumulado de esta complicación es del 2-5\% por año en los primeros 10 años de evolución de la enfermedad, del 5-10\% anuales durante la segunda década y del $12-20 \%$ por año a lo largo de la tercera década (2-5). La colitis izquierda presenta un aumento similar del riesgo de CCR, una década más tarde que en las formas más extensas $(6,7)$. Actualmente, se acepta que la displasia constituye un estadio previo al desarrollo de CCR y su presencia en biopsias de la mucosa cólica, especialmente si es de alto grado, o si se asocia a lesiones o masas (DALM), predice la coexistencia de un carcinoma o una situación de alto riesgo $(5,8)$. Con el fin de reducir la mortalidad por CCR en estos pacientes se recomienda la realización de colonoscopias periódicas con toma de numerosas biopsias para detectar displasia (9-11). En nuestro medio se desconoce la incidencia del CCR postcolítico y de la displasia, por lo que no queda probada la rentabilidad de esta estrategia.

Este trabajo pretende ser un estudio piloto que nos aproxime a la realidad y permita planificar otro prospectivo que determine la incidencia de la displasia y del CCR en pacientes con CU de larga evolución en España.

\section{MATERIAL Y MÉTODOS}

Se trata de un estudio piloto, prospectivo y observacional en pacientes con el diagnóstico firme de CU de larga evolución a los que se propuso entrar en un programa de vigilancia endoscópica del CCR.

\section{Fuente y características de los pacientes}

Los enfermos incluidos en el programa de vigilancia endoscópica del CCR postcolítico procedían de la consulta monográfica de enfermedad inflamatoria intestinal de nuestro hospital y habían firmado el consentimiento informado. Los datos demográficos de los enfermos están parcialmente recogidos en la tabla I. Un total de 39 pacientes fueron incluidos de forma consecutiva en el programa de vigilancia, desde enero de 1994 hasta diciembre de 2003. La relación H/M fue de 1 y la edad media de 52 \pm 13 años. La duración media de la CU fue de 17,8 \pm 8 años. La media del tiempo de inclusión en el programa fue de 4,6 55 años y se realizaron una media de 2,5 \pm 2 colonoscopias por paciente. Trece $(35 \%)$ enfermos presentaban una colitis izquierda y $26(65 \%)$ una pancolitis o colitis extensa.

\section{Definiciones}

Diagnóstico de $C U$ : se estableció de acuerdo con hallazgos endoscópicos sugestivos (mucosa eritematosa, edematosa, ulcerada y con fragilidad vascular espontánea o por contacto) e histológicos compatibles y un seguimiento de más de 8 años.

Extensión de la CU: se determinó mediante la exploración endoscópica del colon durante un brote agudo de la enfermedad.

1. Pancolitis: la lesión sobrepasa el ángulo hepático del colon.

2. Colitis: extensa la lesión sobrepasa el ángulo esplénico sin sobrepasar el ángulo hepático.

3. Colitis izquierda: la lesión sobrepasa el recto sin sobrepasar el ángulo esplénico.

$C U$ de larga evolución: se consideró como aquella de más de 8 años de evolución en el caso de la pancolitis y la colitis extensa, y de más de 10 años en la forma izquierda.

Displasia: se definió como la proliferación neoplásica de las células epiteliales de la mucosa cólica en remisión inflamatoria sin signos de invasión de la submucosa. El diagnóstico fue verificado por al menos dos anatomopatólogos de plantilla.

Grados de displasia: la displasia de bajo grado o leve se definió como aquella en la que la mayoría de los núcleos de las células neoplásicas se localizan en el polo inferior de las glándulas, mientras que la displasia de alto grado o grave es aquella en la que existía una mayor desestructuración celular.

Terapéutica de mantenimiento con 5-ASA: los enfermos sometidos a esta medicación tomaban un mínimo de $1,2 \mathrm{~g}$ de 5-ASA de forma indefinida, y desde su diagnostico y sólo interrumpida durante los periodos de tratamiento estereoideo.

\section{Métodos}

A todos los pacientes con el diagnóstico de CU de más de 8 años de evolución y extensión mayor a $15 \mathrm{~cm}$, se les propuso someterse a vigilancia toda la mucosa del colon afectada por la enfermedad. Para descartar la presencia de displasia cólica y/o de carcinoma de colon asociado a CU, los pacientes que aceptaron entrar en el estudio fueron sometidos a una colonoscopia en periodos de remisión clínica de la enfermedad y cada 18-24 meses con toma de múltiples biopsias. El número total de biopsias osciló entre 25 y más de 30 en los enfermos con colitis extensa o pancolitis y de 10-15 en los enfermos con colitis izquierda. No se tomaron muestras de la mucosa que nunca estuvo afectada por la enfermedad. Estas muestras fueron revisadas por dos patólogos que determinaron la presencia de: displasia su grado y la de carcinoma. En la figura 1 se describe el manejo de los pacientes en función de los hallazgos endoscópicos e histológicos. En ausencia de displasia, los pa- 
cientes fueron sometidos a revisiones endoscópicas periódicas con toma de biopsias, cada 18-24 meses. En el caso de detectar displasia en el seno de una mucosa con signos endoscópicos e histológicos de inflamación, se indicaría la realización de una nueva exploración con toma de biopsias tras la remisión completa de la inflamación. En presencia de displasia leve sin signos de inflamación de la mucosa, se indicaría una nueva endoscopia con toma de muestras a los tres meses. En caso de displasia grave sin inflamación, se realizaría una nueva exploración con toma de biopsias 4 semanas después de la anterior. Por último, ante el hallazgo de displasia grave no asociada a inflamación en dos exploraciones consecutivas, el paciente sería remitido a cirugía para una pancolectomía profiláctica. La variable principal fue la aparición de displasia en el programa de vigilancia endoscópica. Otras variables evaluadas fueron la duración de la enfermedad, la presencia o no de actividad endoscópica en caso de que se detectase displasia, la regresión de la displasia tras la administración de tratamiento de mantenimiento con 5-ASA.

\section{Análisis estadístico}

Se realizó un estudio estadístico descriptivo, calculando la media y la desviación estándar para las variables cuantitativas, y el porcentaje y el intervalo de confianza del 95\% (IC 95\%) para las variables cualitativas. Se utilizó el paquete estadístico SPSS 11.0.

\section{RESULTADOS}

Se detectó la presencia de displasia leve en 4 pacientes, en uno de ellos en dos ocasiones separados por 5 años (13\%, IC 95\%: 6,1-33,5), la incidencia de displasia leve fue de $1,3 \%$ pacientes por año de vigilancia. No se detectaron displasias graves ni CCR. En la tabla I se resumen las características de los pacientes con y sin displasia leve en las biopsias de la mucosa cólica. De las 5 displasias leves detectadas, $4(80 \%)$ se presentaban sobre una mucosa con signos endoscópicos de inflamación aguda, a pesar de que los pacientes carecían de síntomas sugerentes de brote agudo. En la tabla II se puede ver el rendimiento del protocolo
Tabla I. Características de los pacientes con displasia leve y sin displasia

\begin{tabular}{lcc}
\hline & Displasia leve & Sin displasia \\
\hline Número & 4 & 35 \\
Sexo (hombre:mujer) & $4: 0$ & $16: 19$ \\
Edad (años)* & $58 \pm 6$ & $51 \pm 14$ \\
Extensión de la colitis ulcerosa & & \\
$\quad$ Pancolitis/Extensa & $4(50 \%)$ & $26(65 \%)$ \\
$\quad$ Izquierda & 0 & $13(35 \%)$ \\
Tiempo de evolución (años)* & $23,2 \pm 6$ & $16,9 \pm 9$ \\
Tiempo de inclusión en el programa & & \\
$\quad$ (años)* & $6,2 \pm 4$ & $4,4 \pm 3$ \\
Númber de colonoscopias con biopsias* & $5,2 \pm 3$ & $1,9 \pm 1$ \\
5-ASA de mantenimiento** & $4(100 \%)$ & $25(64 \%)$ \\
\hline
\end{tabular}

*Media \pm desviación estándar; **estos enfermos nunca estuvieron sometidos a inmuno-moduladores como terapia de mantenimiento.

Tabla II. Tiempo de inclusión en el programa de vigilancia endoscópica y número de lesiones displásicas

\begin{tabular}{lcc}
\hline $\begin{array}{l}\text { Tiempo de inclusión en el } \\
\text { programa (years) }\end{array}$ & $\begin{array}{c}\mathbf{N}^{\circ} \text { de } \\
\text { pacientes }\end{array}$ & $\begin{array}{c}\text { Lesiones } \\
\text { displásicas }\end{array}$ \\
\hline$<3$ años & $25(64 \%)$ & $1^{*}$ \\
$3-5$ años & $8(20 \%)$ & 0 \\
$>5$ años & $6(15 \%)$ & $4^{* *}$ \\
\hline
\end{tabular}

*1 año desde su inclusión en el programa de vigilancia, pero 20 años de evolución de CU extensa; **2 displasias leves en un mismo paciente.

de seguimiento de los enfermos afectados de CU de larga evolución. En la tabla III se muestran las características de los cuatro enfermos en los que se detectaron lesiones displásicas. No se expresan niveles de significación por que el escaso número de displasias encontradas hacen poco fiable cualquier resultado estadístico.

\section{DISCUSIÓN}

No se detectó ningún caso de carcinoma ni de displasia de alto grado en nuestros pacientes. Cabe destacar que todas las displasias leves menos una se observaron sobre una mucosa inflamada, a pesar de que los pacientes no presentaban sintomatología de brote agudo de enferme-

Tabla III. Características de los pacientes con CU y displasia leve

\begin{tabular}{|c|c|c|c|c|c|c|c|c|c|}
\hline Pacientes & Sexo & Edad & $\begin{array}{l}\text { Extensión } \\
\text { UC }\end{array}$ & $\begin{array}{c}\text { Tiempo } \\
\text { evolución (años) }\end{array}$ & $\begin{array}{c}\text { Tiempo } \\
\text { vigilancia (años) }\end{array}$ & $\begin{array}{l}\text { Número de } \\
\text { endoscopias }\end{array}$ & $\begin{array}{c}\text { Actividad } \\
\text { endoscópica }\end{array}$ & $\begin{array}{l}\text { Repetición } \\
\text { biopsias }\end{array}$ & 5-ASA \\
\hline 1 & Varón & 51 & Pancolitis & 19 & 7 & 4 & Sí & No displasia & Sí \\
\hline 2 & Varón & 58 & Colitis extensa & 20 & 1 & 2 & Sí & No displasia & Sí \\
\hline 3 & Varón & 60 & Pancolitis & 21 & 7 & 7 & Sí & No displasia & Sí \\
\hline 4 & Varón & 65 & Colitis extensa & 33 & 10 & 9 & No & No displasia & Sí \\
\hline
\end{tabular}

CU: colitis ulcerosa; 5-ASA: 5-aminosalicilatos 
dad lo que hace sospechar que eran lesiones reactivas. Así mismo, todas ellas regresaron tras administrar tratamiento con dosis altas de 5-ASA entre uno y tres meses. No se observó una asociación o progresión de la displasia leve a displasia de alto grado o carcinoma. Estos resultados son acordes con la impresión clínica de que el CCR asociado a $\mathrm{CU}$ no es frecuente entre nuestros pacientes $\mathrm{y}$ discrepan de la experiencia acumulada por otros grupos (1-8).

Resulta difícil explicar la razón de estos sorprendentes resultados y podrían ser un sesgo derivado del reducido número de pacientes incluidos en el programa, agravado por el corto periodo de seguimiento. Así mismo, podrían intervenir otros factores como el alto porcentaje de pacientes en tratamiento con 5-ASA, que parece tener un efecto protector frente al desarrollo del CCR (9-17), o la diferente incidencia del CCR en la población general del área, que es menos de la mitad de la observada en otros países occidentales (18).

Aunque no dispongamos de otro método diagnóstico mejor en la práctica clínica, es posible que la incidencia de displasia entre los enfermos de colitis ulcerosa no sea representativa de la incidencia del carcinoma asociado a CU. El verdadero valor predictivo de la displasia leve en la detección del CCR es aún objeto de controversia. En los primeros estudios su utilidad parecía escasa, puesto que tan sólo un 16-29\% de los casos progresaban a lesiones más agresivas $(5,8,12)$. Con la unificación de los criterios histológicos, ha mejorado la especificidad de este marcador en la detección de lesiones malignas. Connell y cols. describieron un aumento de su valor predictivo desde un $16 \%$ inicial a un $54 \%$, tras revisar 128 biopsias compatibles con displasia de bajo grado (12). Ullman y cols., tras 32 meses de seguimiento, al reevaluar las biopsias procedentes de 18 pacientes con CU de larga evolución y displasia leve, observaron una progresión de las lesiones en el $50 \%$ de los casos con una incidencia acumulada de displasia de alto grado o carcinoma del $33 \%$ a los 5 años (14). En un trabajo más reciente, el mismo autor describe una progresión de la displasia de bajo grado en un $30 \%$ de los pacientes, con una tasa de progresión del 53\% a los 5 años (19). En cambio, otro trabajo detectó la progresión de la displasia leve en tan sólo un $10 \%$ de los casos tras revisar las biopsias de una cohorte de 128 pacientes vigilados durante 10 años (20).

Existe una gran variabilidad inter e intraobservador en el diagnóstico histológico de la displasia leve, con una concordancia entre patólogos expertos de tan sólo un 50$60 \%$ (21-22). Esto, añadido a la imposibilidad de biopsiar todo el colon, elevaría el número de falsos positivos, y lo que es más grave, de falsos negativos. Creemos que en nuestro programa de vigilancia, el número de biopsias tomadas y el tramo del colon explorado son suficientes. Dado que la displasia es parcheada (20), la American Gastroenterological Association (AGA), la American Society of Gastrointestinal Endoscopy (ASGE) y la British Society of Gastroenterology (12,23), recomiendan realizar una exploración completa del colon, independientemente de la extensión de la enfermedad, y tomar 2-4 biopsias cada $10 \mathrm{~cm}$. Ello se traduce en mayores costes y molestias para el paciente. Además de que, la inmensa mayoría de los tumores y las lesiones premalignas se encuentran en los tramos más distales del colon y hasta el $25 \%$ de los carcinomas postcolíticos no se asocian a la presencia de displasia (19,24-27). Por todo ello, estas recomendaciones han sido clasificadas como "grado C", es decir, con tan sólo moderada evidencia respecto a su eficacia, donde los beneficios son muy similares a los perjuicios, lo que no aconseja su aplicación de forma generalizada (28).

Por lo que antecede y por tratarse de un pequeño estudio piloto nuestros resultados hay que tomarlos como una aproximación a la realidad. Para establecer la relación coste/beneficio de un programa de cribaje del carcinoma postcolítico habrá que realizar estudios amplios, prospectivos y multicéntricos con el fin de determinar la verdadera incidencia del CCR en la CU de larga evolución en nuestro medio.

\section{AGRADECIMIENTOS}

Este estudio ha sido financiado en parte por una beca concedida por el Instituto de Salud Carlos III (C03/02). 